\title{
An Appraisal of Insect Pests Associated with Cereal Grains Traded in Maiduguri, Borno State, Nigeria
}

\author{
D. M. Mailafiya* ${ }^{*}$ Z. Dauda, M. M. Degri, B. G. J. Kabir, Y. T. Maina \\ Department of Crop Protection, Faculty of Agriculture, University of Maiduguri, \\ P. M. B. 1069, Maiduguri, Nigeria \\ *E-mail address: dmailafiya@gmail.com
}

\begin{abstract}
This study investigated insect pest infestation of maize, millet, sorghum, rice and wheat grains traded in the three main markets namely Monday, Baga-Road and Custom-Park markets in Maiduguri, Borno state, Nigeria. Sampling lasted from January to June 2012. Samples per grain type, each weighing one kilogram, were obtained every two weeks from ten randomly selected traders per market. Each sample was sieved in the laboratory to recover all adult insects present, both at sampling and also after one month stay (laid out in a completely randomized design). In each market, Sitophilus zeamais Motschulsky and Rhyzopertha dominica (F.) followed by Tribolium castaneum Herbst, Sitophilus oryzae (Linnaeus), Trogoderma granarium (Everts) or Cryptolestes sp. were the insect pests commonly found attacking more (between two to five) grain types. Observed highest and lowest mean insect numbers were respectively by $S$. zeamais in maize grains (12.13 individuals in Monday market) and $T$. granarium in wheat grains (0.13 individuals in Baga-Road market). Results unveil that among three markets, higher mean total numbers of insects were present in maize, rice or wheat (1833). For all grain types, the mean numbers of damaged grains were significantly higher in Monday (53-357) and Custom-Park (46-302) than in Baga-Road (17-109) markets. Furthermore, the mean total number of damaged grains across markets was significantly higher maize, followed by rice and wheat (55-231) than in other grain types (37-41). The implications of all these results on insect infestation of different cereal grain types sold in these markets are discussed.
\end{abstract}

Keywords: Stored-product-insect pests; cereal grain infestation; insect abundance; grain types; traded and damaged grains

\section{INTRODUCTION}

Cereal grains production and marketing provide vital income and human nutrition to the inhabitants of sub-Saharan Africa, which by extension, positively impacts food security attainment and maintenance in the continent. The bulks $60-80 \%$, of cereal grains harvested across the continent are by subsistence farmers, and as such, are generally stored from a few hundred kilograms to a few tons in traditional/local stores on-farm and/or within the confines of farmer dwellings for household consumption, marketing or seed preservation purposes (Giga et al., 1992; Ngamo et al., 2007). On average 60-90\% of stored commodities last six months to one year, during which, food grain losses especially under poor storage conditions and in the absence of postharvest management practices have been reported to reach between 
25-40 \% (Dichter, 1976; FAO, 1994; Ivbijaro, 1989; Odogola, 1994; Adejumo and Raji, 2007).

This $25-40 \%$ damage is due to attack of primary and secondary pests. Primary (i.e., Sitophilus spp., Rhyzopertha dominica (F.), Sitotroga spp., Prostephanus truncatus (Horn)) and secondary (i.e., Tribolium spp., Oryzaephilus spp., Plodia interpunctella (Hubner), Corcyra cephalonica (Stainton) insect pests that respectively infest or penetrate intact grains and broken/damaged grains and flour are of great concern for grain loss. Grain loss in both quantity and quality results from insect feeding, reproduction and stored produce contamination with exuviae, webbing and cadavers.

Insect presence alone can lead to increased grain respiration from heightened temperature and moisture contents that provide suitable conditions for storage microorganisms to cause further spoilage (Udoh et al., 2000). Annual losses in Africa due to insect pest attack in different grain types averagely falls between 20-50\% (Youdeowi and Service, 1986; Philips and Throne, 2010). Reduction and prevention of such food grain losses in storage, thus becomes imperative, for food security in terms of nutritional food availability, accessibility and utilization are targets.

In Nigeria and particularly the northern savanna region, 40-85\% of food grains harvested are stored traditionally and averagely over 3 to 12 months (Ivbijaro, 1989). Longer grain storage periods of between 7-10 years have also been reported in this region, where annual food grain losses have been documented in the range of 40-60\% (Youdeowei and Service, 1986; Ivbijaro, 1989; Adejumo and Raji, 2007). Efforts by the Federal, State and Local Governments as well as the private sector in Nigeria for enhanced production of cereal grains including maize (Zea mays L.), pearl millet (Pennisetum glaucum (L.) R. Br.), rice (Oryza sativa L.), sorghum (Sorghum bicolour (L.) Moench) and wheat (Triticum aestivum L.) in the agriculturally marginal areas of the Sudano-Sahelian savanna agroecological zone and the Lake Chad Basin continues to increase.

Huge quantities of grains sourced from across the entire north eastern region of the country are sold in the various markets of Maiduguri, the Borno state capital, virtually throughout each year. However, there is very little or no information on the volume of cereal grain trade sustained in the various markets and the insect pest problems experienced during different stages of processing and handling on the journey to consumers or utilization. This study therefore investigated insect pest abundance in five major cereal grain types sold in the three main markets situated in Maiduguri.

\section{MATERIALS AND METHODS}

Maiduguri in Borno State - Nigeria, lies between latitudes $11045^{\prime} \mathrm{N}$ to 11051 ' $\mathrm{N}$ and longitudes $1302^{\prime} \mathrm{E}$ to $1309^{\prime} \mathrm{E}$. The elevation above sea level ranges between 320 and 354 meters. It borders the Sudan and Sahel savanna regions of Nigeria where rainfall is erratic and ranges from $250 \mathrm{~mm}$ to $900 \mathrm{~mm}$ per annum.

The climate is semi-arid, with mean monthly minimum and maximum temperatures respectively ranging from $14{ }^{\circ} \mathrm{C}$ to $25^{\circ} \mathrm{C}$ and $31{ }^{\circ} \mathrm{C}$ to $40{ }^{\circ} \mathrm{C}$. Being the state capital of Borno state (comprised of 27 Local Government Areas), huge quantities of cereal (sorghum, millet, maize etc) and legume (cowpea, groundnut, bambara nut etc.) grains produced all over the state and even beyond, get transported to and traded in Maiduguri's three main markets namely Monday, Custom-Park and Baga-Road markets. 


\section{1. Data Collection}

Samples of maize, millet, rice, sorghum and wheat grains sold in each of the three main markets including Monday, Baga-Road and Custom-Park markets in Maiduguri were procured from randomly selected traders. Ten samples of each grain type were obtained per market at each sampling, conducted fortnightly from January to June 2012. Each one kilogram (kg) (or approximately two small measures) grain sample placed in a labeled polythene bag was taken to the Entomology Laboratory, Department of Crop Protection, University of Maiduguri. Grain sample infestation was determined by counting the number of adult insect pests present. Upon sieving each grain sample, insects collected were identified and counted. All grain samples placed in separate plastic jars were laid out in a completely randomized design, and then kept in the laboratory for one month. After which, each grain sample was sieved again so as to recover, identify and count all emerged insects. This allowed for grains containing immature insect pests at sampling to be included in the observation. To assess grain damage, 1000 grains were randomly taken from each sample and separated into whole or undamaged and damaged grains. The number of grains in each category was noted and used to compute percent grain damage per sample.

\section{2. Data analysis}

Insect abundance and percent damaged grains amongst species, grain types or markets were analyzed using Kruskal-Wallis $(H)$ at $\mathrm{P}=0.05$ (SAS, 2001). Where significant, means were separated using Nemenyi tests.

\section{RESULTS}

Six insect pests were recovered from five cereal grain types sold in three markets within Maiduguri (Table 1).

Table 1. Insect pest species recovered from five different cereal grain types sold in three markets in Maiduguri.

\begin{tabular}{|c|c|c|c|}
\hline Insect species & Order: Family & Market & Cereal grains \\
\hline Sitophilus zeamais Motschulsky & Coleoptera: Curculionidae & $\mathrm{Mm}, \mathrm{Br}, \mathrm{Cp}$ & $\mathrm{Mt}, \mathrm{Mz}, \mathrm{Rc}, \mathrm{Sg}, \mathrm{Wh}$ \\
\hline Sitophilus oryzae (Linnaeus) & Coleoptera: Curculionidae & $\begin{array}{c}\mathrm{Mm}, \mathrm{Cp} \\
\mathrm{Br}\end{array}$ & $\begin{array}{c}\mathrm{Mz}, \mathrm{Rc}, \mathrm{Wh} \\
\mathrm{Mz}, \mathrm{Rc}\end{array}$ \\
\hline Trogoderma granarium (Everts) & Coleoptera: Dermestidae & $\begin{array}{c}\mathrm{Cp} \\
\mathrm{Br} \\
\mathrm{Mm}\end{array}$ & $\begin{array}{l}\mathrm{Mt}, \mathrm{Mz}, \mathrm{Wh} \\
\mathrm{Sg}, \mathrm{Wh} \\
\mathrm{Mt}, \mathrm{Mz}, \mathrm{Rc}\end{array}$ \\
\hline Cryptolestes sp. & Coleoptera: Cucujidae & $\begin{array}{c}\mathrm{Mm} \\
\mathrm{Cp}, \mathrm{Br}\end{array}$ & $\begin{array}{l}\mathrm{Mz}, \mathrm{Wh} \\
\mathrm{Mz}, \mathrm{Rc}\end{array}$ \\
\hline $\begin{array}{l}\text { Tribolium castaneum Herbst } \\
\text { Rhizopertha dominica }(\mathrm{F} .)\end{array}$ & $\begin{array}{l}\text { Coleoptera: Tenebrionidae } \\
\text { Coleoptera: Bostrychidae }\end{array}$ & $\begin{array}{l}\mathrm{Mm}, \mathrm{Br}, \mathrm{Cp} \\
\mathrm{Mm}, \mathrm{Br}, \mathrm{Cp}\end{array}$ & $\begin{array}{c}\mathrm{Mt}, \mathrm{Mz}, \mathrm{Sg}, \mathrm{Wh} \\
\mathrm{Mt}, \mathrm{Mz}, \mathrm{Rc}, \mathrm{Sg}, \mathrm{Wh}\end{array}$ \\
\hline
\end{tabular}

Sitophilus zeamais Motschulsky and Rhyzopertha dominica (F.) were the most common pest species found attacking five different cereal grains (maize, millet, rice, sorghum and wheat) sold in all three markets (Monday, Baga-Road and Custom-Park markets) under 
study. Tribolium castaneum (Herbst) was recovered from four grain types sold in all the three markets. Sitophilus oryzae (Linnaeus), Trogoderma granarium (Everts) and Cryptolestes sp. were however, found infesting two to three different cereal grain types in any one or two of the markets.

Based on species per grain type and market, the mean abundance of $S$. zeamais together with $R$. dominica (in Monday market $(H 4,139=25.9, \mathrm{P}=0.0001)$ ), $T$. castaneum (in BagaRoad market $(H 4,139=15.5, \mathrm{P}=0.0001))$ or both $R$. dominica and $T$. castaneum (in Custom-Park market $(H 4,139=33.1, \mathrm{P}=0.0001))$ were significantly higher than other insect pests found attacking maize. With the exception of Monday market $(H 3,139=15.2, \mathrm{P}=$ $0.0027)$, where $R$. dominica was more abundant than other insects pests, mean pest abundance was not significantly different in millet grains sold in Baga-Road $(H 2,139=1.2$, $\mathrm{P}=0.6657)$ and Custom-Park $(H 3,139=0.8, \mathrm{P}=0.1175)$ markets. In rice, $S$. oryzae singly (in Monday $(H 3,139=44.3, \mathrm{P}=0.0001)$ and Custom-Park $(H 3,139=22.2, \mathrm{P}=0.0001)$ markets) or together with $S$. zeamais and $R$. dominica in Baga-Road market $(H 3,139=26.7$, $\mathrm{P}=0.0001)$ had more mean number of individuals than other insect pests. Rhizopertha dominica in Monday $(H 2,139=18.9, \mathrm{P}=0.0001)$ or Custom-Park $(H 2,139=15.1, \mathrm{P}=$ $0.0001)$ markets and T. granarium in Baga-Road market $(H 1,21=23.5, \mathrm{P}=0.0001)$ were significantly more abundant than other insect pests attacking sorghum grain. Sitophilus zeamais and $R$. dominica in Monday market $(H 4,139=8.4, \mathrm{P}=0.0001), R$. dominica and $T$. castaneum in Baga-Road market $(H 3,127=21.5, \mathrm{P}=0.001)$ and $R$. dominica, $T$. castaneum and $S$. oryzae in Custom-Park market $(H 4,139=11.8, \mathrm{P}=0.001)$ were significantly higher in mean abundance than other insect pests infesting wheat grain.

According to grain type per market, the mean total abundance of insects infesting maize and rice grains, followed by wheat grain were significantly higher than those attacking millet and sorghum grains sold in Monday market $(H 4,694=48.2, \mathrm{P}=0.0001)$. In Baga-Road market $(H 4,694=9.5, \mathrm{P}=0.0001)$, mean total insect abundance from wheat, rice and sorghum grains were significantly higher than that from maize and millet grains. The mean total abundance of insect pests attacking maize and rice grains were significantly higher than from millet, sorghum and wheat grains $(H 4,694=31.3, \mathrm{P}=0.0001)$. Based on grain type across all markets, the mean total number of insects infesting maize and rice grains were significantly higher in Monday Market, followed by Custom-Park Market than in Baga-Road market $(H 2,415=19.6, \mathrm{P}=0.0001)$. For millet and wheat, the mean total number of insects attacking these grains were significantly higher in Monday market than in Baga-Road and Custom-Park markets $(H 2,415=26.2, \mathrm{P}=0.0001)$. The mean total number of insects infesting sorghum grains was likewise only significantly higher in one market, Baga-Road, than in Monday and Custom-Park markets $(H 2,415=7.9, \mathrm{P}=0.0001)$.

Across markets per grain type, the mean number of bored maize grains was significantly higher in Monday market, followed by Custom-Park market than in Baga-Road market $(H 2,415=13.9, \mathrm{P}=0.0001)$. By contrast, the mean number of bored rice grains was significantly higher in Custom-Park market followed by Monday market than in Baga-Road market $(H 2,415=21.0, \mathrm{P}=0.0001)$. The mean number of bored sorghum and wheat grains were significantly higher in both Monday and Custom-Park markets than in Baga-Road market $(H 2,415=32.0, \mathrm{P}=0.0001)$, whereas that from millet grain was only significantly higher in Custom-Park market than in Monday and Baga-Road markets (H2, $415=11.9, \mathrm{P}=$ 0.0001). Across markets and grain types, the mean total number of bored holes in maize, followed by rice and wheat grains were significantly higher than obtained in millet and sorghum $(H 4,694=8.5, \mathrm{P}=0.0001)$. 
Table 2. Mean numbers of insect species attacking five different cereal grain types sold in three markets in Maiduguri.

\begin{tabular}{|c|c|c|c|c|c|}
\hline \multirow{2}{*}{$\begin{array}{c}\text { Insect species / } \\
\text { Market }\end{array}$} & \multicolumn{5}{|c|}{ Grains } \\
\hline & Maize & Millet & Rice & Sorghum & Wheat \\
\hline \multicolumn{6}{|l|}{ Monday market } \\
\hline Sitophilus zeamais & $12.13 \pm 3.42 b$ & $2.84 \pm 0.95 \mathrm{a}$ & $5.13 \pm 1.09 \mathrm{a}$ & $3.13 \pm 0.75 \mathrm{a}$ & $5.58 \pm 1.22 b$ \\
\hline Sitophilus oryzae & $2.71 \pm 0.33 \mathrm{a}$ & - & $16.8 \pm 4.23 b$ & - & $3.73 \pm 0.99 a$ \\
\hline Trogoderma granarium & $2.05 \pm 0.44 \mathrm{a}$ & $2.12 \pm 0.83 \mathrm{a}$ & $1.25 \pm 0.22 \mathrm{a}$ & - & - \\
\hline Cryptolestes sp. & $3.38 \pm 1.01 \mathrm{a}$ & - & - & - & $2.15 \pm 0.97 \mathrm{a}$ \\
\hline Tribolium castaneum & $4.75 \pm 0.98 \mathrm{a}$ & $4.05 \pm 1.61 \mathrm{a}$ & - & $2.45 \pm 0.91 \mathrm{a}$ & $1.74 \pm 0.88 \mathrm{a}$ \\
\hline Rhizopertha dominica & $7.01 \pm 2.02 \mathrm{ab}$ & $5.63 \pm 1.13 b$ & $8.89 \pm 2.25 \mathrm{a}$ & $8.25 \pm 2.11 b$ & $10.11 \pm 3.17 b$ \\
\hline Total & $32.85 \pm 12.11 \mathrm{Cz}$ & $15.59 \pm 3.44 \mathrm{Ay}$ & $28.32 \pm 5.06 \mathrm{Cz}$ & $12.34 \pm 3.92 \mathrm{Ax}$ & $25.61 \pm 10.03 \mathrm{Bz}$ \\
\hline \multicolumn{6}{|l|}{ Baga-Road market } \\
\hline Sitophilus zeamais & $4.79 \pm 0.55 b$ & $3.12 \pm 1.04 \mathrm{a}$ & $4.51 \pm 1.04 \mathrm{~b}$ & $1.19 \pm 0.42 \mathrm{a}$ & $1.01 \pm 0.15 \mathrm{a}$ \\
\hline Sitophilus oryzae & $0.23 \pm 0.08 \mathrm{a}$ & - & $9.74 \pm 2.10 \mathrm{~b}$ & - & - \\
\hline Trogoderma granarium & - & - & - & $10.12 \pm 2.19 b$ & $0.13 \pm 0.04 \mathrm{a}$ \\
\hline Cryptolestes sp. & $2.62 \pm 0.88 \mathrm{a}$ & - & $0.89 \pm 0.26 \mathrm{a}$ & - & - \\
\hline Tribolium castaneum & $8.13 \pm 1.15 b$ & $3.63 \pm 0.54 \mathrm{a}$ & - & $1.14 \pm 0.63 \mathrm{a}$ & $3.55 \pm 0.57 b$ \\
\hline Rhizopertha dominica & $2.05 \pm 0.77 \mathrm{a}$ & $4.23 \pm 1.02 \mathrm{a}$ & $3.82 \pm 0.37 \mathrm{~b}$ & $3.31 \pm 0.91 \mathrm{a}$ & $6.75 \pm 1.99 b$ \\
\hline Total & $13.27 \pm 5.04 \mathrm{Ax}$ & $11.05 \pm 1.22 \mathrm{Ax}$ & $18.25 \pm 1.55 \mathrm{Bx}$ & $17.82 \pm 3.99 \mathrm{By}$ & $19.40 \pm 8.05 \mathrm{Bx}$ \\
\hline \multicolumn{6}{|l|}{ Custom-Park market } \\
\hline Sitophilus zeamais & $8.11 \pm 2.79 b$ & $3.31 \pm 0.09 \mathrm{a}$ & $4.72 \pm 0.23 \mathrm{a}$ & $2.73 \pm 0.56 \mathrm{a}$ & $2.89 \pm 0.08 \mathrm{a}$ \\
\hline Sitophilus oryzae & $0.89 \pm 0.25 \mathrm{a}$ & - & $7.82 \pm 2.50 b$ & - & $4.21 \pm 0.31 \mathrm{ab}$ \\
\hline Trogoderma granarium & $3.01 \pm 1.01 \mathrm{a}$ & $1.72 \pm 0.76 \mathrm{a}$ & - & - & $5.91 \pm 1.33 b$ \\
\hline Cryptolestes sp. & $2.75 \pm 0.15 \mathrm{a}$ & - & $2.75 \pm 0.79 \mathrm{a}$ & - & - \\
\hline Tribolium castaneum & $4.92 \pm 0.17 \mathrm{~b}$ & $2.64 \pm 0.50 \mathrm{a}$ & - & $2.33 \pm 0.82 \mathrm{a}$ & $1.66 \pm 0.98 \mathrm{a}$ \\
\hline Rhizopertha dominica & $9.41 \pm 0.71 b$ & $3.45 \pm 0.77 \mathrm{a}$ & $3.13 \pm 0.35 \mathrm{a}$ & $7.33 \pm 1.61 \mathrm{~b}$ & $4.61 \pm 0.71 b$ \\
\hline Total & $25.13 \pm 9.08 \mathrm{By}$ & $12.89 \pm 1.54 \mathrm{Ax}$ & $17.97 \pm 5.22 \mathrm{By}$ & $13.47 \pm 2.38 \mathrm{Ax}$ & $20.21 \pm 6.14 \mathrm{By}$ \\
\hline
\end{tabular}

Table 3. Mean numbers of damaged grains per 1000 grains of five different cereal grain types sold in three markets in Maiduguri.

\begin{tabular}{cccccc}
\hline \multirow{2}{*}{ Market } & \multicolumn{5}{c}{ Grains } \\
\cline { 2 - 6 } & Maize & Millet & Rice & Sorghum & Wheat \\
\hline Monday market & $356.59 \pm 85.24 \mathrm{c}$ & $33.65 \pm 9.47 \mathrm{a}$ & $130.16 \pm 32.90 \mathrm{~b}$ & $52.75 \pm 11.12 \mathrm{~b}$ & $69.64 \pm 19.22 \mathrm{~b}$ \\
Baga-Road market & $109.13 \pm 24.08 \mathrm{a}$ & $21.88 \pm 6.31 \mathrm{a}$ & $94.62 \pm 25.01 \mathrm{a}$ & $17.02 \pm 5.16 \mathrm{a}$ & $41.71 \pm 12.22 \mathrm{a}$ \\
Custom-Park market & $302.23 \pm 51.67 \mathrm{~b}$ & $77.25 \pm 16.13 \mathrm{~b}$ & $225.63 \pm 64.90 \mathrm{c}$ & $46.41 \pm 10.71 \mathrm{~b}$ & $58.63 \pm 15.32 \mathrm{~b}$ \\
Mean & $231.15 \pm 62.15 \mathrm{D}$ & $40.93 \pm 33.72 \mathrm{~A}$ & $133.42 \pm 15.04 \mathrm{C}$ & $37.11 \pm 8.03 \mathrm{~A}$ & $55.25 \pm 7.92 \mathrm{~B}$ \\
\hline
\end{tabular}




\section{DISCUSSION AND CONCLUSIONS}

Based on current results, all five cereal grain types under study were infested by various insect pests in all three markets. In attacking each cereal grain type sold in all the markets, $S$. zeamais and $R$. dominica, seemed to be the predominant stored product pests in these grains. Of the six insect pest species recovered in this study, the host range (cereal grain types) of $S$. oryzae, T. granarium, Cryptolestes sp. and T. castaneum varied with markets. Given the significantly higher numbers of $S$. zeamais and $R$. dominica respectively attacking maize and sorghum grains in different markets, our results align with those of Halliday (1966), who similarly found Sitophilus spp. and Rhyzopertha spp. as the key insect pests infesting stored sorghum and maize grains sold in Kano state within the Sudan savannah agroecological zone of Nigeria. Studies by Ayertey and Ibitoye (1987) further showed that Sitophilus spp., Rhyzopertha spp. and Sitotroga spp. accounted for $57 \%$ to $84 \%$ of all insects infesting maize and sorghum grains sold in about 50 markets located in three contagious climatic conditions in northern Nigeria. The authors also found that $R$. dominica and Sitophilus spp. strongly preferred sorghum grain over maize in three different agroecological zones, but that the prevalence of these insect pests especially, Sitotroga spp., was more in the Southern- and Northern Guinea savannah zones than in the Sudan savannah zone. Additionally, S. zeamais, Sitotroga cerealella (Olivier) and Tribolium spp. were documented to be the major insect pests of maize in northern Nigeria (Ayertey, 1980).

The recovery of Sitotroga spp. in the above two studies, but not in this one suggests that the species are at the edge of their distribution within the Sudan savannah agroecological zone, and therefore, are scarce in the Sudano-Sahelian agroecological zone of Nigeria. In addition to being generally low across the agroecological zones of northern Nigeria, the incidence of Sitotroga spp. was earlier observed to progressively decrease northwards across three agroecological zones namely the Southern Guinea, Northern Guinea and Sudan savannah (Ayertey and Ibitoye, 1987). Significantly higher numbers of $R$. dominica and $S$. oryzae over other insect pests in all or some of the markets studied, suggests that both species are important pests in wheat and rice grains respectively in at least parts of the region. The restriction of higher abundance of $T$. granarium to only two cereal grain types (sorghum in Baga-Road market and wheat in Custom-Park market), and each within a given market, was totally unclear. The authors also couldn't explain reasons for the following results: i) the none significant difference amongst insect pests infesting millet grains sold in most (>half) of the markets, ii) variations (across markets) in the mean number of bored grains as well as the total number of insect pests per cereal grain type, and iii) the low relative abundance and host range of Cryptolestes sp. across markets. Nevertheless, the results patterns were thought to be greatly influenced by any or a combination of the following: i) the quantity of cereal grains handled and marketed by traders in these markets including the practice(s) and frequency of grain(s) re-stocking, ii) the quality of grains obtained as well as the length and conditions of storage, and iii) pest management practices employed.

Grain damage due to insect infestation, for instance, increases with increased storage duration (Giles, 1964b and Caswell, 1979). In terms of cereal grain type, the relatively higher number of insect pests found attacking maize, rice and wheat grains than millet and sorghum in different markets indicates that the former three grain types suffer more damage in storage from insect pests attack in this region. For maize grains that are seriously attacked by insect pests pre- and whilst in storage, this is not surprising as insect infestation often positively correlates with the resultant grain damage caused (Ayertey, 1980; Ayertey and Ibitoye, 1987). Preharvest insect damage and weight loss of maize grains in northern Nigeria have 
been reported at $14 \%$ and $20 \%$, respectively (Ayertey, 1980). Though observed to increase from $7 \%$ during the dry season to $12 \%$ in the rainy season (Caswell, 1980), insect pests damage after six months maize storage have been reported to range between $7 \%$ and $21 \%$ in the same region (Ayertey and Ibitoye, 1987). Similar to the rates (low) observed in this study, previous works had documented relatively low annual damage rates due to insect pests attack of between $1 \%$ and $4 \%$ of stored sorghum grains in northern Nigeria (Giles, 1964a; Caswell, 1979). Although very high sorghum grain damage (88\%) and weight loss (37\%) levels have been reported in northern Nigeria (Giles, 1964a); the results were very likely from grains stored in the southern parts of the northern savanna region of Nigeria, where its major pests, Rhyzopertha spp. and Sitophilus spp. are more prevalent and prefer sorghum to maize (Ayertey and Ibitoye, 1987). Moreover, the generally high atmospheric moisture owing to heavy rainfall or humidity southwards of Nigeria from the northern parts should allow for relatively greater grain moisture content that can support high insect infestation rates. Insect infestation of maize grains in the southern parts of Nigeria was for example found to be much high (61.8-78 \%) (Adesuyi and Shode, 1977) compared to that obtained in the northern parts of the country (7.7 \% and $20.9 \%$ ) (Ayertey and Ibitoye, 1987).

\section{References}

[1] Ayertey J. N. (1980). Infestation of and damage to preharvest maize in Samaru and Daudawa, northern Nigeria. Paper presented at the $10^{\text {th }}$ Annual Conference, Nigerian Society for Plant Protection, Zaria, Nigeria.

[2] Ayertey J. N., Ibitoye J. O., Insect Sci. Appli. 8 (1987) 981-987.

[3] Adesuyi S. A., Shode D. A., Nig. J. Plant Protect. 3 (1977) 98-101.

[4] Caswell G. H. (1979). Damage to stored sorghum in the northern part of Nigeria. Institute for Agricultural Research, Samaru, Zaria, pp. 22.

[5] Caswell G. H. (1980). A review of the work done in the Entomology Section of the Institute for Agricultural Research on the pests of stored grain. Samaru Miscellaneous Paper, 99.

[6] Dichter D., The stealthy thief. Ceres (FAO Review) 9 (1976) 51-53, 55.

[7] FAO (1994). Grain storage techniques. Evolution and trends in developing countries. FAO Agricultural Bulletin No. 109.

[8] Giga D. P., Ampofo J. K. O., Silim M. N., Negasi F., Nahimana M., Msolla S. N. (1992). Onfarm storage losses due to bean bruchids and farmers' control strategies: a report on a travelling workshop in eastern and southern Africa. Occassional Publication Series No.

8. Cali, Colombia: CIAT

[9] Giles P. H. (a), Trop. Agric. 41 (1964) 197-212.

[10] Giles P. H. (b), Bull. Entomol. Res. 55 (1964) 573-588.

[11] Halliday D., Insect damage to foods on sale in a Kano market. Report of the Nigerian Stored Product Research Institute. Technical Report 13 (1966) 103-107.

[12] Hayma J. (2003). The storage of tropical agricultural products. Agrodok No. 31. Agromisa Foundation, Wageningen, Netherlands. 
[13] Ivbijaro M. F. (1989). Evaluation of existing storage systems for grains and tubers and loss estimates at different points in the distribution and marketing chain. In: A Study of Private Sector Participation in National Food Storage Programme, Federal Department of Agriculture. Peat Marwick Management Consultants, Nigeria, pp. 6-8.

[14] Ngamo L. S. T., Ngassoum M. B., Mapongmetsem P. M., Maliasse F., Hauburg E., Lognay G., Hance T., Agric. J. 2 (2007) 242-247.

[15] Odogola W. R. (1994). Postharvest management and storage of food legumes. Technical Systems for Agriculture. AGROTEC UNDP/OPS, Harare, Zimbabwe.

[16] Philips T. W., Throne J. E., Annl. Rev. Entomol. 55 (2010) 375-397

[17] SAS (2001). PROC user's manual. Version 6th ed. SAS Institute, Cary NC.

[18] Udoh J. M., Cardwell K. F., Ikotun T., J. Stored Prod. Protect. 36 (2000) 187-201.

[19] Youdeowei A., Service M. W. (1986). Pest and vector management in the tropics. English Language Book Society/Longman, Singapore. 